\title{
Kunnskap kan gi ungdom bedre psykisk helse
}

Ungdom kan få bedre psykisk helse av å lære om hva som faktisk gir god psykisk helse. Det er derfor viktig at det undervises i temaet i videregående skole.

\section{Forfattere}

\section{Hanne Nissen Bjørnsen}

Helsesøster, Doktorgradsstipendiat

NTNU, Institutt for samfunnsmedisin og sykepleie; Senter for helsefremmende forskning,

\section{Regine Ringdal}

Doktorgradsstipendiat, Rådgiver

Institutt for samfunnsmedisin og sykepleie Fakultet for medisin og helsevitenskap Norges teknisk-naturvitenskapelige universitet (NTNU); Senter for helsefremmende forskning, Trondheim kommune

\section{Mary-Elizabeth Eilertsen}

Førsteamanuensis, dr philos

NTNU, Institutt for samfunnsmedisin og sykepleie; Senter for helsefremmende forskning

\section{Geir-Arild Espenes}

Professor

Institutt for samfunnsmedisin og sykepleie; Senter for helsefremmende forskning

\section{Nina Stiklestad Holmen}

Helsesøster og psykiatrisk sykepleier, Prosjektleder MEST

BFT Heimdal, Tiller vgs

\section{Unni Karin Moksnes}

Førsteamanuensis

NTNU, Institutt for samfunnsmedisin og sykepleie; Senter for helsefremmende forskning 
Sykepleien 2018 106(65075)(e-65075)

DOI: https://doi.org/10.4220/Sykepleiens.2018.65075

\section{HOVEDBUDSKAP}

Denne studien har sett på sammenhengen mellom kunnskap om god psykisk helse og opplevd psykisk velvære hos ungdom i videregående skole: der resultatene viste en klar positiv sammenheng. De som hadde god kunnskap om faktorer som er viktig for god psykisk helse rapporterte markant høyere grad av psykisk velvære enn de som hadde lite kunnskap. Disse resultatene støtter at undervisningsopplegg med mål om å fremme kunnskap om hva som opprettholder og styrker psykisk helse hos ungdom er viktig.

Psykiske utfordringer blant unge har de siste årene fått økende oppmerksomhet i Norge (1). Verdens helseorganisasjon (WHO) påpeker at arbeidet med å fremme god psykisk helse og forebygge psykisk uhelse skal være ressursorientert og med mål om å øke bevissthet og engasjement hos den enkelte (2). Å jobbe ressursorientert er det motsatte av å jobbe problemfokusert. Det innebærer å fokusere på tilgjengelige ressurser ungdommene har, hva som skal til for å ta vare på og bygge god psykisk helse.

Skolehelsetjenesten er en viktig del av helsetjenestene for ungdom i Norge; det er en lavterskeltjeneste bemannet av blant annet helsesøstre som gjennom sin utdanning har særlig kompetanse innenfor helsefremmende og forebyggende arbeid blant barn og unge.

I helsedirektoratets nye retningslinjer for skolehelsetjenesten er det en sentral anbefaling om at skolehelsetjenesten bør arbeide for å fremme god psykisk helse hos elevene (יㅡ). I lys av en slik anbefaling kommer spørsmålet om hvordan tjenesten skal jobbe for å følge opp anbefalingen? 
Skolehelsetjenestens oppgaver er både individrettet og folkehelsebasert, og består blant annet av å drive forebyggende og helsefremmende arbeid blant ungdom, prevensjonsveiledning og foreskriving, gjennomføring av helseundervisning, samt oppfølging og henvising av ungdommer som har behov for det. I dette arbeidet inngår helseopplysning og undervisning om psykisk helse som en naturlig del av skolehelsetjenestens ansvarsområde, der helsesøster har en viktig funksjon i arbeidet med å fremme god psykisk helse hos ungdom.

\section{三 «I Trondheim kommune jobbes det med å fremme god psykisk helse hos ungdom.»}

I Trondheim kommune jobbes det med å fremme god

psykisk helse hos ungdom gjennom en ny

arbeidsstrategi utviklet av og for helsesøstre, arbeidsstrategien har fått navnet MEST (4). MEST er utviklet for bruk i skolehelsetjenesten, også med tanke på et tettere tverrfaglig samarbeid med skolen, fysioterapeuter, psykologer, skoleleger, og eventuelt andre aktører.

Gjennom MEST får ungdom en kartlegging i begynnelsen av skoleåret der de får fortelle hva de har behov for. Ut fra denne kartleggingen tilbyr skolehelsetjenesten åpne seminar for hele skolen, målrettet klasseromsundervisning og tilbud om gruppevirksomhet. Hvis ungdommen kjenner på utfordringer med behov for individuell samtale oppfordres ungdommene til å ta kontakt med helsesøster.

\section{HVA ER MEST?}

MEST er et helsefremmende tilbud fra skolehelsetjenesten til ungdom i i videregående skole med fokus på mestring av normale hverdagsutfordringer. 
Ungdomstiden karakteriseres av mange endringer i ungdommenes liv. Ungdomstiden innebærer blant annet økende grad av uavhengighet fra foreldre, og forventninger om å ta større ansvar for eget liv. I det inngår utviklingen av evner til å ta beslutninger, samt se konsekvenser av disse avgjørelsene, også når det gjelder helse (므). Ungdomstiden er utfordrende for mange, men det er også livsfase med muligheter for å fremme helse, inkludert det å tilegne seg og forsterke eksisterende kunnskap om å ta vare på egen helse, både fysisk og psykisk (6). Det er gjennom forsking allerede blitt identifisert at psykisk helse er et helseområde der ungdom selv uttrykker behov for mer kunnskap og mer undervisning (므).

\section{三 «Ungdom selv uttrykker behov for mer kunnskap.»}

I litteraturen benyttes uttrykket mental health literacy (MHL) eller «psykisk helsefremmende kompetanse» (). . Med psykisk helsefremmende kompetanse menes det å være i stand til å ta gode valg til fordel for egen og andres psykiske helse. Psykisk helsefremmende kompetanse er sammensatt av fire komponenter: 1) å forstå hvordan man fremmer og opprettholder god psykisk helse, 2) å forstå hva psykisk sykdom er og at det finnes behandling, 3) å redusere stigma knyttet til psykisk sykdom og 4) å vite når, hvor og hvordan man kan søke hjelp for psykisk sykdom, samt kjenne til selvhjelpsstrategier (ㅁ). 
Å fremme god psykisk helse gjennom økt psykisk helsefremmende kompetanse hos ungdommene fremstår som en naturlig oppgave for helsesøster i skolehelsetjenesten og da også MEST, da vi vet at psykisk helsefremmende kompetanse er en viktig ressurs og viktig faktor for psykisk helse (5). Forskning har vist at det er en sammenheng mellom lav psykisk helsefremmende kompetanse og psykisk uhelse som for eksempel depresjon (10), mens det ikke er funnet forskning på sammenhengen mellom det å forstå hvordan man fremmer og opprettholder god psykisk helse og opplevd psykisk velvære.

\section{三 «Psykisk helsefremmende kompetanse er en viktig ressurs.»}

Med bakgrunn i MEST sitt arbeid, WHO, som påpeker at fokuset i arbeidet med å fremme psykisk helse skal være ressursorientert, samt skolehelsetjenestens retningslinjer, som understreker skolehelsetjenestens ansvar når det kommer til å fremme god psykisk helse hos elevene, var målet med denne studien å undersøke sammenhengen mellom kunnskap om god psykisk helse og ungdommenes opplevde psykisk velvære, det vil si følelsen eller opplevelsen av å ha det godt.

\section{Spørreundersøkelse}

Resultatene baserer seg på svar fra en spørreundersøkelse der 2981 elever ved fem videregående skoler i Sør-Trøndelag ble spurt om å besvare et spørreskjema ved oppstart av skoleåret 2016/2017 (12, 16). Lærere ved skolene delte ut spørreskjema til 2145 av elevene på skolene. Av dem som fikk tilbud om å svare på spørreundersøkelsen returnerte 97 prosent av elevene spørreskjema som de brukte en skoletime til å svare på. Til sammen ble 1888 elever inkludert i studien, men på grunn av manglende svar på enkelte spørsmål ble 1227 elever inkludert $\mathrm{i}$ analysene. 
Det var en jevn kjønnsfordeling blant elevene og gjennomsnittsalderen på dem som svarte var 17 år med en overvekt (68 prosent) av elever ved studiespesialisering. Informasjon til elevene om deltakelse i studiet ble formidlet av lærere, gjennom informasjonsskriv og en informasjonsvideo som ble lagt ut på skolens e-lærings plattform (for eksempel it’s learning). Det ble fremhevet at det var frivillig å delta i undersøkelsen og at det ikke hadde noen konsekvenser for elevene dersom de ikke ønsket å delta. Elever som ikke ønsket å delta kunne jobbe med lekser eller annet skolearbeid. Elever som var 15 år hadde skriftlig samtykke fra foreldre for å delta, mens elever over 15 år samtykket ved å fylle ut spørreskjema. Studien er godkjent av REK midt (REK midt 2014/1996).

\section{Instrumenter}

Elevenes kunnskap om faktorer som er viktig for god psykisk helse ble undersøkt ved hjelp av skalaen «Mental Health Promoting Knowledge» MHPK-10 eller «psykisk helsefremmende kunnskap» på norsk (12). MHPK-10 måler komponent 1 av psykisk helsefremmende kompetanse; kunnskap om hvordan fremme og opprettholde god psykisk helse. Skalaen baserer seg på tre komponenter som predikerer god psykisk helse; autonomi, tilhørighet og kompetanse (11). Skalaen består av ti utsagn som elevene skal rangere på en 6-punkts skala, og går fra «helt feil» til «helt riktig», samt vet ikke representert av 0, der høyere score indikerer høyere grad av kunnskap. MHPK-10 er validert blant norsk ungdom (12).

Psykisk velvære ble undersøkt ved hjelp av «WarwickEdinburgh Mental Well-Being Scale» WEMWBS. WEMWBS består av 14 utsagn som måler psykisk velvære, der elevene ble bedt om å rangere hvert utsagn på en 5-punkts skala fra «ikke i det hele tatt» til «hele tiden». Høyere score indikerer høyere psykisk velvære. WEMWBS er brukt og validert blant norsk ungdom $(\underline{13}, \underline{14})$. 
I studien ble det også kontrollert for andre variabler som kan påvirke psykisk velvære. I analysene ble derfor kjønn, alder, studieretning, foreldres utdanning, familieøkonomi, ensomhet, stress og selvrapportert fysisk helse også inkludert som faktorer som kan forklare psykisk velvære.

Stata versjon 14.2 ble brukt til de statistiske analysene (15).

\section{三 «Ensomhet og stress var relatert til lavere psykisk velvære»}

\section{Resultat}

Resultatene viser at de inkluderte variablene til sammen forklarer 41 prosent av variasjonen i psykisk velvære hos de spurte ungdommene, der kunnskap om god psykisk helse viser seg å være en viktig faktor (16). Resultatene viser også at blant annet økende grad av ensomhet og stress var relatert til lavere psykisk velvære. Fysisk helse, kjønn og familieøkonomi var positivt assosiert med psykisk velvære. Det vil si at gutter, og de som rapporterte høyere familieøkonomi og mer positiv fysisk helse, også rapporterte høyere psykisk velvære.

Når det gjelder alder ser vi at 18-åringer rapporterte høyere psykisk velvære enn 16-åringer, ellers var det ingen avgjørende forskjeller i aldersgruppen 15-21 år. Studieretning og mors utdanning viste ingen betydelig sammenheng med ungdommenes psykiske velvære.

\section{三 «Vi anser at helsesøster er en riktig profesjon til å bidra med opplæring i psykisk helse.»}

\section{Betydning for praksis}


I arbeidet med å bedre psykisk helse hos ungdom

gjennom økt kunnskap, har flere studier vist at å

fokusere slik som MEST gjør; med fokus på god

psykisk helse fremfor å forebygge psykiske lidelser har

vært en effektiv tilnærming $(\underline{17}, \underline{18})$.

I løpet av de siste to tiår er skolen identifisert som en

viktig arena for helsefremming for barn og unge (19).

Resultatene fra denne undersøkelsen gir oss viktig kunnskap og gir en indikasjon på retningen en bør arbeide i for å fremme psykisk helse hos ungdom i en skolesetting. Vi ser at å fokusere på kunnskap om god psykisk helse kan være gunstig for ungdommenes psykiske velvære.

\section{三 «Resultatene kan ha betydning for hva som inkluderes i undervisning om psykisk helse.»}

Resultatene kan ha betydning for hva som inkluderes i undervisning om psykisk helse til ungdom i videregående skole. Vi fant at 41 prosent av variasjonen i ungdommenes psykiske velvære forklares av kjønn, alder, studieretning, foreldrenes utdanningsnivå, familieøkonomi, ensomhet, stress, egenrapportert fysisk helse og kunnskap. Kunnskap viste seg å være en viktig faktor for psykisk velvære hos ungdommene.

Funnene fra denne studien viser at det er viktig å inkludere psykisk helsefremmende kunnskap i opplæringen i skolen rettet mot å fremme god psykisk helse hos de unge slik som MEST gjør.

(Artikkelen fortsetter under bildet.) 


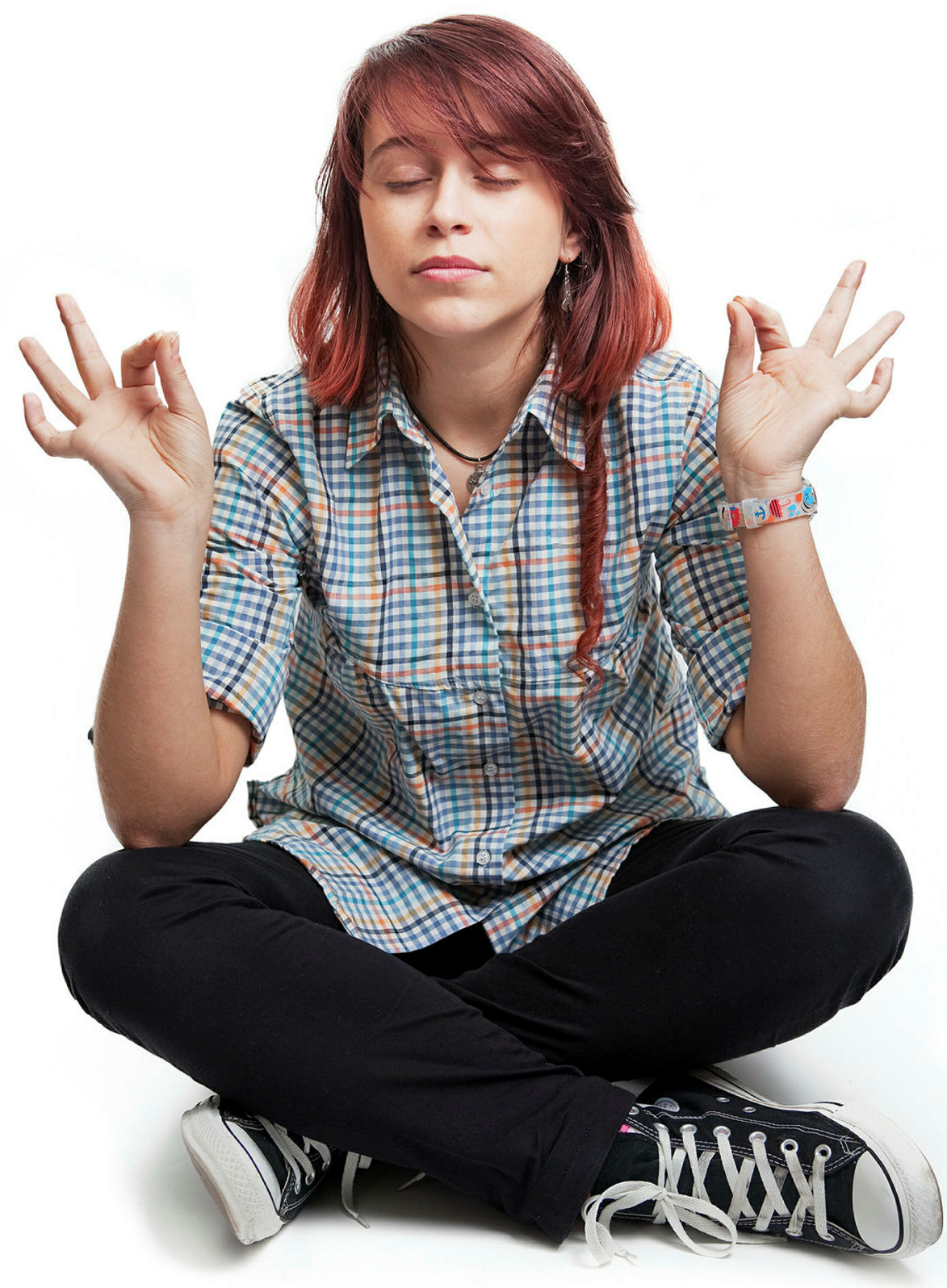

VELVÆRE: Avslapningsteknikker kan bidra til økt psykisk velvære. Illustrasjonsfoto: Mostphotos 
Psykisk helsefremmende kunnskap baserer seg på tre komponenter som har vist seg å predikere god psykisk helse; autonomi, tilhørighet og kompetanse (11). Kompetanse referer til det å oppleve seg selv som kompetent til å mestre eget liv, autonomi referer til det å ha en egen fri vilje og det å ta valg og handle ut ifra egne verdier og ønsker. Mens tilhørighet handler om å være en del av et sosialt miljø, det å føle at man hører til og bryr seg om andre (20).

Elementer fra disse komponentene som kan brukes i praktisk undervisning vil være for eksempel avslapningsteknikker, normalisere følelsesmessige variasjoner og reaksjoner, stressmestring, søvnhygiene, selvbilde, kjenne egne grenser, selvbestemmelse, kroppsbilde og hvordan sette grenser for egen atferd. MEST tilbyr seminar på disse tema som ungdom selv sier de har behov for. Det er ønskelig at ungdommene selv skal ta et valg på hvor de vil hente kunnskapen. Åpne frivillige seminar, klasseromsundervisning, grupper eller i en individuell samtale.

Denne studien viser at det er viktig også å adressere stress, ensomhet og fysisk helse i tillegg til kunnskap, når man jobber for å fremme god psykisk helse hos ungdom. Andre faktorer som viser seg å påvirke psykisk velvære hos ungdom som foreldrenes utdanningsnivå, familieøkonomi, alder og kjønn er umulig for skolehelsetjenesten å endre, men likevel nyttig å kjenne til i psykisk helsefremmende arbeid med ungdom. Ettersom det er funnet en klar sammenheng mellom kunnskap om god psykisk helse og psykisk velvære er det viktig å finne gode måter å spre kunnskap på til ungdom, der MEST tjener som ett eksempel.

\section{Oppsummering}


Resultatene fra denne undersøkelsen kan brukes som et ledd i utviklingen av en kunnskapsbasert skolehelsetjeneste med en helsesøster som også underviser om faktorer som er viktig for å fremme og opprettholde god psykisk helse, sammen med helsesøstres og skolehelsetjenestens erfaringer og elevenes ønsker. Å finne gode metoder for å fremme psykisk helse hos ungdom er et viktig ansvarsområde for skolehelsetjenesten.

Vi anser at helsesøster er en riktig profesjon til å bidra med opplæring i psykisk helse i skolen fordi helsesøster har spesialkompetanse innen helsefremming og forebygging og skal være tilgjengelig for ungdommene på skolen. Helsesøster i skolen bør antakelig derfor være både den som koordinerer arbeidet med på fremme psykisk helse blant elevene i skolen og den som har den daglige kontakten med elevene om denne problematikken.

Denne studien har gitt indikasjoner på at det er en sammenheng mellom ungdommenes kunnskap om god psykisk helse og psykisk velvære. I Trondheim kommune er arbeidsstrategien MEST i utvikling med tanke på hvordan skolehelsetjenesten kan jobbe for å fremme elvenes psykiske helse gjennom økt kunnskap. Det vil være viktig å videre studere MEST og strategiens innvirkning på elevens kunnskapsnivå og psykiske helse.

\section{Referanser:}

1. Sletten MA, Bakken A. Psykiske helseplager blant ungdom - tidstrender og samfunnsmessige forklaringer. En kunnskapsoversikt og en empirisk analyse. Oslo: Velferdsforskningsinstituttet NOVA, Høgskolen i Oslo og Akershus; 2016. NOVA Notat 4/16. 
2. World Health Organization. Promoting mental

health: concepts, emerging evidence, pratice. Genève:

WHO; 2005.Tilgjengelig fra:

http://www.who.int/mental_health/evidence/MH_Promotion_Book.pdf

(nedlastet 30.10.2017).

3. Helsedirektoratet. Helsestasjons- og

skolehelsetjenesten. Nasjonal faglig retningslinje for

det helsefremmende og forebyggende arbeidet $\mathrm{i}$

helsestasjon, skolehelsetjeneste og helsestasjon for

ungdom. Oslo: Helsedirektoratet; 2017. Tilgjengelig

fra:

https://helsedirektoratet.no/retningslinjer/helsestasjons-

og-skolehelset... (nedlastet30.102017).

4. Charlottenlund vgs. MEST-mestring-av-

hverdagsutfordringer [internett]. Trondheim:

Charlottenlund videregående skole [sitert 08.12.2017].

Tilgjengelig fra:

http://charlottenlund.vgs.no/Aktiviteter/MEST-

mestring-av-hverdagsutfo...

5. Broder J, Okan O, Bauer U, Bruland D, Schlupp S, Bollweg TM, et al. Health literacy in childhood and youth: a systematic review of definitions and models. BMC Public Health. 2017;17(1):361.

6. Mulye TP, Park MJ, Nelson CD, Adams SH, Irwin CE, Jr., Brindis CD. Trends in adolescent and young adult health in the United States. Journal of Adolescent Health. 2009;45(1):8-24.

7. Smart KA, Parker RS, Lampert J, Sulo S. Speaking up: teens voice their health information needs. Journal of School Nursing. 2012;28(5):379-88.

8. Språkrådet. Literacy. Oslo: Språkrådet; 2017.

Tilgjengelig fra:

http://www.sprakradet.no/svardatabase/sporsmal-og-

svar/literacy/ (nedlastet 30.10.2017). 
9. Kutcher S, Wei Y, Costa S, Gusmao R, Skokauskas $\bar{N}$, Sourander A. Enhancing mental health literacy in young people. Eur Child Adolesc Psychiatry. 2016;25(6):567-9.

10. Lam LT. Mental health literacy and mental health status in adolescents: a population-based survey. Child and Adolescent Psychiatry and Mental Health.

2014;8(26).

11. Deci E, Vansteenkiste M. Self-determination theory and basic need satisfaction: understanding human development in positive psychology. Ricerche Di Psicologia. 2004;27(1):23-40.

12. Bjornsen HN, Eilertsen MEB, Ringdal R, Espnes GA, Moksnes UK. Positive mental health literacy: development and validation of a measure among Norwegian adolescents. BMC Public Health. 2017;17(1):717.

13. Putz R, O’Hara K, Taggart F, Stewart-Brown S. Using WEMWBS to measure the impact of your work on mental well-being: a practice-based user guide. NHS Health Scotland; 2012.

14. Ringdal R, Bradley Eilertsen ME, Bjornsen HN, Espnes GA, Moksnes UK. Validation of two versions of the Warwick-Edinburgh Mental Well-Being Scale among Norwegian adolescents. Scandinavian journal of public health. 2017:1403494817735391.

15. StataCorp. Stata statistical software: release 14 . College Station: StataCorp LP; 2015.

16. Bjornsen HN, Espnes GA, Eilertsen MB, Ringdal $\mathrm{R}$, Moksnes UK. The relationship between positive mental health literacy and mental well-being among adolescents: implications for school health services. Journal of School Nursing. 2017:1059840517732125. 
17. Weare K, Nind M. Mental health promotion and problem prevention in schools: What does the evidence say? Health Promotion International. 2011;26(S1).

18. O'Mara L, Lind C. What do we know about school mental health promotion programmes for children and youth? Advances in School Mental Health Promotion. 2013;6(3):203-24.

19. Leger LS, Young I, Blanchard C, Perry M.

Promoting health in schools. From evidence to action. International Union for Health Promotion and Education (IUHPE). Contract No.: 24.5.

20. Ng JY, Ntoumanis N, Thogersen-Ntoumani C, Deci EL, Ryan RM, Duda JL, et al. Self-determination theory applied to health contexts: a meta-analysis. Perspect Psychol Sci. 2012;7(4):325-40. 